Social Work \& Education

Ryabukha, I. (2018). Співвідношення академічного та професійного підходів у вищій освіті на зламі століть (на прикладі морської освіти), Social Work and Education, Vol. 5, No. 1., pp. 121-129.

() SW\&E, 2018

Ivan Ryabukha,

PhD, Head of the Department of English Language for Marine Officers (Abridged Programme), Kherson State Maritime Academy, Kherson, Ukraine, r.i.m_17@ukr.net

\section{Іван Рябуха,} кандидат педагогічних наук, завідувач кафедри англійської мови з підготовки морських фахівців за скороченою програмою, Херсонська державна морська академія, м. Херсон, Украӥна

УДК 371.13

DOI:10.25128/2520-6230.18.1.12

Article history:

Received: March 01, 2018

1st Revision: March 17, 2018

Accepted: March 27, 2018

\section{СПІВВІДНОШЕННЯ АКАДЕМІЧНОГО ТА ПРОФЕСІЙНОГО ПІДХОДІВ У ВИЩІЙ ОСВІТІ НА ЗЛАМІ СТОЛІТЬ (НА ПРИКЛАДІ МОРСЬКОЇ ОСВІТИ)}

АНОТАЦІЯ. Стаття присвячена питанню співвідношення професійного та академічного підходів до надання морської вищої освіти. Метою статті $\epsilon$ аналіз глобалізаційних процесів у вищій освіті на прикладі морської освіти. Освіта може бути інструментом соціальних змін для підтримки статусу кво у суспільстві. Будь-яка освіта повинна розглядатися у контексті суспільства i оцінюватись в залежності від іiі впливу на особистість - на ії майбутнє. Разом із законодавством і ринком, освіта, будучи чинником установлення соціальних норм, $€$ ключовим інструментом для соціальних змін. Традиційна підготовка моряків завжди фокусувалась на отримання та використання практичних навичок, необхідних для роботи на борту судна. Сучасний тренд у вищій освіті загалом і морській, зокрема, - поєднувати професійну підготовку 3 академічною через зростаючий попит молоді до отримання саме вищої освіти з однісї сторони і використанням все більш технічно складних механізмів та електронних приладів на судні, 3 іншої. Причиною цього $є$ соціально-економічний розвиток країн та технологічні новації у морській індустрії. Наведений аналіз застосування цього тренду в різних країнах світу. Особливу увагу приділено проблемі співвідношення надання практичних навичок та здатності критично мислити у ракурсі компетентнісно-орієнтованої освіти, яка визначена основним підходом до навчання й підготовки моряків. Поєднання професійних компетентностей $\mathrm{i}$ емпіричних здібностей $\mathrm{y}$ підготовці моряків є основною проблемою морської освіти XXI ст. Виявлено певну невідповідність між національними освітніми стандартами й вимогами морської індустрії, які прописані у Міжнародній конвенції про підготовку та дипловування моряків і несення вахти. Узагальнено, що уявна різниця між академічною і професійною морською освітою поступово зникає. Морські заклади вищої освіти сформували багаторівневу структуру i пропонують постійно-діючі сертифікаційні курси підвищення кваліфікації. Це усе в комплексі відповідає основному трендові освіти XXI ст. навчання впродовж життя.

Ключові слова: морська освіта; професійно-академічна вища освіта; компетентнісно-орієнтований підхід; глобалізація; ПДНВ; морська індустрія. 


\section{Вступ}

Реформування систем освіти у різних країнах світу, їх входження у світовий освітній простір ставлять науку перед необхідністю розробки певної глобальної стратегії професійної підготовки фахівців (особливо морських) за рахунок активного залучення ресурсу світового досвіду в області вищої освіти без втрати унікальності національних академічних культур.

Потреба сучасної економіки у компетентних фахівцях здатних до постійної адаптації у швидкозмінних умовах професійної діяльності та готових до навчання впродовж життя висуває нові серйозні вимоги до їхньої підготовки, особливо у закладах вищої освіти. Як зазначається у Законах України «Про освіту», «Про вищу освіту», у «Національній доктрині розвитку освіти України в ХХІ столітті» та інших державних нормативних документах, навчання у закладі вищої освіти має забезпечити як загальну професійну підготовку фахівця, так і його спеціалізацію, спрямовану на певний вид діяльності в конкретних умовах.

Водночас, пріоритети морської освіти визначаються не лише у вітчизняних стратегічних документах, але, у першу чергу, в міжнародних конвенціях та деклараціях і стають освітніми орієнтирами для усіх країн світу. Україну, як європейську країну, не можуть оминути всі вищеназвані процеси.

Поволі стає зрозумілішим, що реорганізація системи морської освіти, вищої освіти загалом та всього суспільства залежить від якості та дієвості вищої школи. Саме тому на перший план виступає проблема створення дієвого освітнього середовища професійно-академічної підготовки майбутнього моряка. Для іiі розв'язання $\epsilon$ необхідним створення механізму реальних змін у вищій освіті, зокрема, розроблення загальної стратегії проектування освітнього середовища професійної підготовки 3 урахуванням надбань національних систем морської освіти. Таке середовище спонукало б до включення кожного майбутнього офіцера флоту до самостійного, особистісно-зорієнтованого процесу професійного розвитку. Це значною мірою стосується підходу до професійної та мотиваційної підготовки викладачів морських закладів вищої освіти, адже їхні якості, компетенції, що формують динамізм, креативність, конструктивність, надалі стимулюватимуть становлення аналогічних якостей особистості майбутніх моряків і $є$ підгрунтям їх подальшого ступеневого професійного зростання.

Зважаючи на це, постає питання актуалізації проблеми уніфікації підходів до освіти і підготовки моряків на засадах глобалізації морської освіти та виокремлення проблемних аспектів даного процесу, що і стало метою нашої статті.

Під час дослідження використовувались методи аналізу та порівняння підходів до вищої освіти у різних країнах світу на прикладі морської освіти.

\section{Аналіз останніх публікацій}

Аналіз літератури свідчить, що вченими грунтовно досліджено умови освіти i підготовки моряків у морських закладах вищої освіти різних країн світу (М. Мануель, В. Ходаковський,С. Волошинов).

У сучасних дослідженнях бачимо привернення особливої уваги до проблеми створення інформаційно-освітнього середовища навчального закладу (I. Захарова, 
С. Малан, К. Кречетников) та до питань функціонування освітнього середовища вищого навчального закладу (Е. Мамонтова, Л. Коіфе, Т. Менг, І. Щендрик).

\section{Основна частина}

Освіта має за мету створення такого середовища, яке б дало змогу призвести до бажаних змін у студентів в сенсі позитивної зміни їх знань та/або навичок чи сприяти зміні їх ставлень та цінностей - усе залежно від цілей навчання. Важливою в контексті нашого дослідження є думка багатьох науковців, зокрема I. Щендрика, що освітнє середовище складається не само по собі і не на основі рекомендацій або побажань, для його виникнення необхідна спеціально організована діяльність, зокрема педагогічна, ефективність якої є лише за умови ії проектування (Щендрик I., 2003, c. 89$)$.

Треба зазначити, що освіта може бути інструментом соціальних змін для підтримки статусу кво у суспільстві. Будь-яка освіта повинна розглядатися у контексті суспільства і оцінюватись в залежності від іiі впливу на особистість - на іiі майбутне, відповідність та доцільність вибору типу освіти особистістю та результатів навчання в контексті їх відповідності вимогам соціуму. Разом із законодавством і ринком, освіта, будучи чинником установлення соціальних норм, $є$ ключовим інструментом для соціальних змін (Мануель М., 2011, с. 214). Розглядаючи можливості оптимізації соціальної політики та бажаних результатів освіти треба брати до уваги не тільки правові норми, але й доповнювати загальну картину відповідними, існуючими на конкретний момент та у конкретній країні, соціальними нормами та ринковими системами, адже вони також $є$ факторами формування соціальної поведінки та загальної соціалізації молоді. Основним дієвим гравцем цього процесу є система формальної освіти. Роль відповідної освіти і підготовки у процесі передачі знань, підтримки компетентності на належному рівні, стимулюванні необхідних змін у суспільстві, зверненні до викликів часу, а також у пом'якшенні негативних наслідків попередніх дій та рішень $є$ абсолютно незаперечною. 3 точки зору соціальних змін затребуваних 3 боку світового суспільства чи конкретної індустрії або країни вища освіта є як продуктом, так і джерелом змін (Куафе Л., 2012). Заклади вищої освіти за своєю природою виконують цю соціальну зміну за допомогою надання вищої освіти. Протягом часу змінювались концепції основного завдання вищої освіти, але в іiі стрижні завжди залишалось - розвивати навички дедуктивного обгрунтування та мистецтво мислення. За словами Дж. Н'юмана «університет не передбачає ані морального впливу, ані механічного виробництва; він не вчить тренувати мозок ані у мистецтві, ані у точних науках; його функція культура мислення; навчивши культурі мислення, університет може заспокоїтись. Він навчає інтелект обгрунтовувати будь-яку річ, добиратися до істини та хапати ії» (Н’юман Дж., 1907, с. 126).

В своїй історично-оригінальній формі заклад вищої освіти (університет), як агент соціальних змін, завжди звертався до фундаментальних питань, які охоплюють усі людські інтереси, цінності та запити - від фізичних та біологічних до психологічних та екзистенціальних. Так склалося історично, що це була ліберальна освіта - розвиток інтелекту задля розвитку інтелекту. Однак, прихильники утилітаризму у всі часи не сприймали такий підхід до освіти. Суспільство та час все 
більше і більше вимагало від закладів вищої освіти практичної направленості та спеціалізації випускників. Саме тому вища освіта еволюціонувала у напрямку обрання практичних цілей, не забуваючи про вищезгадану мету. Заклади вищої освіти (3ВО) повинні бути здатними «адаптувати постійні соціально-економічні запити до радикальних змін у науці та культурі мислення» (Скот П., 1993, с. 4). 3ВО має розглядатися з точки зору перспектив у освіті, соціуму, політиці та економіці; вони $€$ посередниками між вченими та студентами -3 однієї сторони $\mathrm{i}$ роботодавцями, політиками, громадою - 3 іншої. Залежно від сили впливу тієї чи іншої сторони, заклад вищої освіти обирає направленість своєї освітньої діяльності або вузькопрофесійну, або загальноакадемічну.

На початку XXI століття утилітарні сили впливу на розвиток закладів вищої освіти отримали перевагу, а отже вища освіта почала орієнтуватись на вузькопрофесійні компетентності, які вимагаються роботодавцями. Цей прагматичний підхід проявився у збільшеній направленості вищої освіти, особливо інженерної, до професійних знань і умінь, які затребувані на виробництві, без задіяння філософських, відірваних від реальності міркувань. Від закладів вищої освіти вимагається не тільки бути науковими та навчальними центрами, але й репозиторіями суспільно-значущих сучасних знань та компетентностей; при цьому не важливо стосуються ці знання виключно емпіричних чи вузькопрофесійних дисциплін. Такий підхід проявився у існування закладів вищої освіти, які надають можливість післядипломної освіти та перепідготовки.

Виявляється, що ідея XIX-початку XX століть стосовно професійної освіти, як такої, що відрізняється від вищої освіти стає все більше анахронізмом. Ця ідея мала право на існування у суспільстві з чітким поділом на класи, де існування «робочого класу» було протиставлене елітному класові інтелігенції 3 вищою освітою. Величезну частка університетських дипломів сьогодні - інженерних, медичних, фармацевтичних, правових, фінансових, архітектурних і морських - можна віднести до розряду «професійно-орієнтованих» за своєю суттю; особливо беручи до уваги дотримання стандартів, вимог і цілей конкретних професій, які висуваються індустрією і суспільством. Не протиставляючи більш академічні напрямки вищої освіти (мистецькі, гуманітарні, емпірично наукові) названим вище, залишається констатувати, що більшість університетів пропонують професійно- та практичноорієнтовані курси навіть для «чистих» науковців в утилітарному контексті XXI століття. Тому проблема вибору між професійною чи академічною освітою i підготовкою для сучасних закладів вищої освіти є питанням семантики. У цьому контексті морська освіта стала однією з передових у насиченні освітнього простору закладів вищої освіти сумішшю емпіричної та вузькопрофесійною складових задля забезпечення відповідності своїх випускників вимогам індустрії. Таким чином поява вищої морської освіти, як такої, у другій половині XX століття є такою ж виправданою, як і будь-якої іншої вузькопрофесійної, яка присутня насьогодні в університетах світу. Таке перепланування цілей та завдань закладів вищої освіти називається дослідниками новою парадигмою освіти, спрямованою на результат (Малан С., 2000, с. 23).

Основною парадигмою, на яку спирається вища освіта сьогодні, є розвиток компетентностей як для професійних цілей, так і для суто емпіричних. У цій новій 
парадигмі, яка об’єднує дослідницькі результати зі спрямованістю на вузькопрофесійний результат, студентам треба ставити завдання критично ставитись до ситуації сьогодення, розвивати когнітивні навички i, водночас, відповідати вимогам професійних стандартів до рівня компетентностей спеціалістів. Таким чином, не відкидаючи розвиток критичного ставлення до реальності, сучасній вищий освіті обов'язково притаманна академічна свобода. Професійна освіта, 3 іншої сторони, традиційно фокусувалась на отриманні практичних навичок і не приділяла достатньої уваги критичному мисленню, як інструменту розвитку особистості. Говорячи прикладами, немає ніякої академічної свободи у процесі спускання якоря на танкері чи безпечній проводці судна у припортових водах за наданою лоцманом схемою руху та розходження суден. Успішне виконання цих практичних завдань залежить від того, чи отримав виконавець певний набір навичок і компетентностей, які, хоча і досить складні, не є такими, що відносяться до суто наукової сфери.

Через те, що морська індустрія є однією 3 найбільш глобалізованих та інтернаціоналізованих, вона пройшла через низку значних змін протягом останнього століття. Вона мала адаптуватися до науково-технічного прогресу та запропонувати тим, хто хоче працювати у цій індустрії змішані стандарти у освіті з огляду на свою специфіку. Потреба у зміні підходу була спричинена також зміною сприйняття студентів того, що саме вони хочуть від життя. Досить нечасто сьогодні можна зустріти молоду людину з розвиненої країни, яка пов'язувала б усе своє життя 3 кар'єрою у морі. Більш того технології, які використовуються у судноплавстві та конструкції суден стають все складнішими, вимоги до безпеки екіпажу та судна - все жорсткішими, умови екологічності судноплавства - все обмеженішими; усе це вимагає від морської освіти застосовувати змішаний академічно-професійний підхід у навчальному процесі.

Таким чином жорсткого розмежування між професійно-технічною та вищою освітою не існує; у крайньому випадку, це можна чітко говорити про морську освіту і підготовку, адже сучасна професійна морська робота потребує навчання впродовж усього життя. Якщо порівняти професійний та академічний підходи до вищої освіти за таксономією Блума, то треба визнати, що основною відмінністю між ними $є$ ступінь спеціалізації освіти. Критичне мислення, яке розвивається закладом вищої освіти у академічному підході знаходить своє відображення у специфічних завданнях професійного підходу. Таким чином можливо говорити лише про ширину та глибину критичного мислення в ракурсі цих підходів, а не розрізняти та не розділяти навички - до професійного, а знання - до академічного.

У більшості країнах світу морські заклади вищої освіти не можуть видати диплом «бакалавра» чи «магістра», якщо студент не пройшов мінімального обсягу практики на судні. Іншими словами, моряк ніколи не зможе стати морським офіцером, а саме диплом про вищу освіту $є$ одним 3 умов для цього, поки не відпрацює практично на рядових посадах на судні - оце і є змішаний професійноакадемічний підхід у дії.

Такий змішаний підхід, який об’єднує можливість отримувати робочі морські дипломи паралельно 3 навчальними дипломами, саме відповідає соціальним i кар'єрним цілям сучасних моряків та надає їм можливість навчатися та просуватися кар’єрною драбиною впродовж усього життя разом з адаптацією до вимог індустрії. 
Такий підхід не з'явився 3 нікуди - історично в усіх країнах світу освіта i підготовка фахівців для морського транспорту була щільно пов'язана з підготовкою кадрів на виробництві. Тільки на початку XX століття, а саме у 1936 році, була зроблена перша спроба виписати певні орієнтири та вимоги до підготовки моряків, які були б сприйняті усіма країнами - Конвенція про компетентність офіцерів (Officers' Competency Certificates Convention). Згідно зі Статтею 3 цієї конвенції «жодна особа не може виконувати ... обов'язки капітана чи шкіпера, вахтового помічника капітана, старшого механіка чи вахтового механіка, якщо вона не має відповідного сертифікату (диплому), який дає право виконувати ці обов'язки» (С053 - Officers' Competency Certificates Convention, 1936). Наступним кроком на шляху до універсалізації морської освіти було прийняття Міжнародної конвенції про підготовку та дипловування моряків і несення вахти (ПДНВ) у 1978 році, яку ратифікували більш ніж сімдесят країн світу. У первозданному вигляді ця конвенція спромоглася проіснувати до 1995 року, коли накопичені суспільно-економічні зміни у світи змусили переглянути та уточнити іiі зміст. У 2010 році з тих же причин були внесені наступні доповнення до конвенції, які і $є$ дійсними до на сьогодні.

Конвенція ПДНВ зберігає професійний підхід до організації освіти і підготовки моряків, який, в першу чергу, зосереджений на мінімальні вимоги до знань, розумінь та навичок $\mathrm{i}$, що найважливіше, на методах демонстрації компетентностей та критеріїв для їх оцінки. Саме це $є$ визначальним для ПДНВ парадигма компетентнісно орієнтованої освіти і підготовки, яка зорієнтована на перевірку результату в дії (тобто на судні).

Хоча ПДНВ розроблялась дещо відокремлено від розвитку теорії навчання та освіти загалом, це не може вважатися негативним фактором; адже основною метою цієї конвенції було зменшення нещасних випадків на борту, забезпечення безпеки мореплавства та екологічності індустрії загалом. Варто зазначити, що у теорії освіти поняття «компетентність» 3'явилося мінімум на десять років пізніше, а у законодавче освітнє поле різних країн це поняття почало входити уже у XXI столітті (наприклад, в Україні компетентність, як результат освіти, законодавчо було зафіксовано тільки 3 прийняттям закону «Про вищу освіту» у 2014 році). Поряд з цим відбувалися певні соціально-економічні зміни, які призвели до того, що молодь розвинених країн почала відмовлятись від морської освіти, віддаючи перевагу кар'єрі «на березі». На такому фоні і відбувався перехід морських навчальних закладів з суто професійної парадигми освіти до змішаної - професійно-академічної.

Жорстка конкуренція професії моряка з іншими «береговими» професіями за вибір вступника змусила вищі морські заклади освіти світу підпорядкувати морську освіту і підготовку до домінантного соціального тренду - отримання навчального диплому (рівня «бакалавр» чи «магістр»). Саме така парадигма надала змогу вищим морським закладам освіти стати привабливими для молоді, яка ще тільки обирає майбутню професію. Навчальний диплом дасть можливість вільної «міграції» між кар'єрою «у морі» і «на березі», але всередині індустрії. Більш того, комбінація посиленої ролі технологій у судноплавстві та конструкції суден і така парадигма освіти нададуть можливість отримання гнучких професіоналів на випадок майбутньої технічної еволюції. 3 іншого боку, така парадигма може призвести до «вимивання» професіоналів з морської практики. Досить тільки поглянути на досвід 
Німеччини, Великобританії, Італії, Іспанії, Польщі та інших розвинених країн, де престижність професії моряка знижувалась пропорційно до підвищення соціальноекономічного розвитку. Якщо поглянути на національну приналежність офіцерського складу світової морської індустрії, то країнами-лідерами у XXI столітті стали Філіппіни (близько 60 тисяч осіб), Україна (близько 36 тисяч осіб) та Росія (близько 35 тисяч осіб). При цьому співвідношення офіцерів та рядового складу серед українців 36 до 10 на користь офіцерів, тоді як у філіппінців - 52 до 82 - на користь рядових (Семпсон Х., 2004, с. 246). Такий стан речей у морській індустрії загалом, і у морській освіті зокрема не може не турбувати ані соціологів, ані політологів, ані педагогів.

Професійно-академічна парадигма морської освіти сприяє підвищенню рівень професійної компетентності моряків ще і тому, що вона змушує морські заклади вищої освіти комбінувати навчальні плани та програми таким чином, щоб підготовка та освіта за ними найкращим чином відповідала запитам індустрії і роботодавців. Але, одночасно, можна стверджувати, що чим більшу кількість дипломованих моряків ми маємо, тим більша їх кількість обирає кар'єру «на березі», що призводить до сильного дефіциту досвідчених офіцерських кадрів у морі. Однак світове суспільство повинне шукати вирішення цих проблем не у напрямку звуження спеціалізацій до суто морських, а у напрямку надання більшої привабливості морській кар'єрі.

Не дивлячись на певні переваги нової парадигми морської освіти, вона висуває також певні виклики, які треба брати до уваги. Серед таких викликів основним $\epsilon$ проектування та запровадження відповідних навчальних планів з урахуванням наявності кваліфікованих науково-педагогічних кадрів та інструкторів, співвідношення часу навчання $\mathrm{i}$ його змісту, підходів до оцінювання набутих компетентностей i, врешті решт, синергії між робочим та навчальним дипломами (наприклад у Німеччині чи Польщі диплом рівня «бакалавр» дає можливість працювати на посаді капітана за умови наявності мінімального плавцензу за ПДНВ, а в Україні капітаном може бути тільки особа 3 дипломом рівня «спеціаліст» чи «магістр» 3 тим же плавцензом).

Якщо говорити про навчальні програми та плани, то вони досить сильно різняться у різних країнах, що залежить у першу чергу від національних стандартів освіти кожної конкретної країни, а також від вимог роботодавців. Якщо брати до уваги точку зору усіх зацікавлених сторін у діяльності морських вищих навчальних закладів стосовно визначення переліку дисциплін, їх послідовності, оцінки компетентностей, то з'ясується досить різнобарвна картина, яка буде складати найоптимальніший вигляд освіти і підготовки моряка. У морських закладах вищої освіти різних країн $є$ різні підходи і це викликає необхідність для пошуку консенсусу, порівняння та отримання найсприятливішого варіанту.

\section{Висновки}

Отже, підсумовуючи, зазначимо, що уявна різниця між академічною та професійною морською освітою поступово зникає. Вже з'являються перші ознаки морських закладів вищої освіти, які пропонують ступеневу морську освіту «від матроса до капітана», i тільки конкретний студент може вирішувати на якому етапі 
йому краще зупинитися. Також ці заклади пропонують постійно-діючі сертифікаційні курси підвищення кваліфікації. Це усе в комплексі відповідає основному трендові освіти XXI століття - навчання впродовж життя. Основною проблемою, яка залишається невирішеною $є$ можливість оптимального поєднання цілей ПДНВ, вузьконаправлених компетентностей моряка 3 академічними універсальними дисциплінами, які є невід’ємним атрибутом вищої освіти.

\section{Література}

Coiffait L. (2012) Higher Education Policy Blog: the five big trends shaping higher education. The Pearson think tank, accessed $11^{\text {th }}$ November. http://thepearsonthinktank.com/2012/the-five-big-trends-shaping-higher-education/

Malan S. P. T. (2000) The "new paradigm" of outcomes-based education in perspective. Journal Family Ecology Consumer Sciences / Tydskrif vir Gesinsekologie en Verbruikerswetenskappe $28: 22-28$.

Manuel M. E. (2011) Maritime risk and organizational learning. Ashgate, London.

Newman J. H. (1907) The idea of a university defined and illustrated. London, New York etc.: Longmans, Green \&Co.

Sampson H. (2004) Romantic Rhetoric, Revisionist Reality: the effectiveness of regulation in maritime education and training. Journal of Vocational Education and Training $56(2): 245-267$.

Scott P. (1993) The idea of the university in the $21^{\text {st }}$ century: a British perspective. British Journal of Educational Studies 41 (1) : 4-25.

Шендрик И. Г. Теоретические основы проектирования образовательного пространства субъекта / И. Г. Шендрик. - Екатеринбург : Изд-во Рос. Гос. Проф. пед ун-та, 2006. - 198 с. 
CORRELATION OF ACADEMIC AND VOCATIONAL TRENDS IN HIGHER EDUCATION AT THE TURN OF THE CENTURY (USING THE EXAMPLE OF MARITIME EDUCATION)

\author{
Ivan Ryabukha, PhD, Head of the Department of English Language for Marine Officers \\ (Abridged Programme), Kherson State Maritime Academy, Kherson, Ukraine, \\ r.i.m17@ukr.net
}

\begin{abstract}
The article is devoted to the issue of correlation of vocational and academic approaches in providing maritime education and training. The aim of the article is to analyze the processes of globalization in the system of higher education using the example of maritime education. Education and training can be the instrument of social changes to maintain status quo in the society. Any kind of education should be considered in the context of society and be evaluated depending on its influence onto an individual in terms of its personal development in future. Alongside with legislation and market, education is the key factor for social changes. Traditionally education and training of seafarers was focused on obtaining and practical utilization of practical skills and competencies required to efficiently perform duties onboard the ship. Modern worldwide trend of higher education, including maritime education, is to combine academic education with vocational training. It is so due to growing demand of modern youth for getting higher education on the one hand, on the other - saturation of modern vessels with state-of-the-art modern electronic, electric and mechanical equipment. The reason for emerging such a trend is social and economic development of countries and innovation technologies entering everyday professional routine of a seafarer. Analysis of this new trend implementation in different countries of the world is given here. Special emphasis is paid to the problem of correlation of training for practical skills and abilities to critical thinking in the context of competency based and result-oriented approaches of modern education. Combination of vocational competences and empiric skills to think critically and analyze in maritime education and training is the main problem of maritime education in the $21^{\text {st }}$ century. There was found out irrelevance between national educational standards and requirements defined by the International Convention on Standards of Training, Certification and Watchkeeping for Seafarers. There was made a conclusion that the difference between academic and vocational education is becoming more and more indistinct due to social, economic and technological factors. Maritime higher educational institutions have designed multileveled education alongside with constant certified refresher training. All these measures correspond to general educational trend of the $21^{\text {st }}$ century - life-long education and training.
\end{abstract}

Key words: maritime education; vocational and academic education; competency based approach; globalization; STCW; maritime industry.

\title{
References
}

Coiffait, L. (2012) Higher Education Policy Blog: the five big trends shaping higher education. The Pearson think tank, accessed $11^{\text {th }}$ November. http://thepearsonthink tank.com/2012/the-five-big-trends-shaping-higher-education/.

Malan, S. P. T. (2000) The "new paradigm" of outcomes-based education in perspective. Journal Family Ecology Consumer Sciences. Tydskrif vir Gesinsekologie en Verbruikerswetenskappe 28:22-28.

Manuel, M. E. (2011) Maritime risk and organizational learning. Ashgate, London.

Newman, J. H. (1907) The idea of a university defined and illustrated. London, New York etc.: Longmans, Green \&Co.

Sampson, H. (2004) Romantic Rhetoric, Revisionist Reality: the effectiveness of regulation in maritime education and training. Journal of Vocational Education and Training. 56 (2) : 245-267.

Scott, P. (1993) The idea of the university in the $21^{\text {st }}$ century: a British perspective. British Journal of Educational Studies. 41 (1) : 4-25.

Shchendryk, I. (2006) Theoretical basis for designing educational environment of an individual. Yekaterinburg. [In Russian]. 
